\title{
Performance of Rabbits Fed Different Levels of Tridax Procumbens in Cassava - Based Rations
}

\author{
T. I. Anthony ${ }^{1}, *$ D. T. Shaahu, ${ }^{2}$ S. A. Ikurior ${ }^{3}$ \\ ${ }^{I}$ Department of Animal Health and Production, Akperan Orshi College of Agriculture Yandev, Gboko, Benue \\ state, Nigeria. \\ ${ }^{2}$ Department of Animal Production, Collage of Animal Science, University of Agriculture, Makurdi. \\ PMB 2373, Makurdi, Benue State, Nigeria \\ ${ }^{3}$ Department of Animal Nutrition, University of Agriculture, Makurdi, Benue State, Nigeria.
}

\begin{abstract}
Twenty - six weeks old rabbits with an average initial weight of $645 \pm 49.37 \mathrm{~g}$ were used in a 12 week feeding trial to evaluate the performance of growing rabbits fed different levels of Tridax procumbens in cassava - based diets. The rabbits were divided into five groups with four rabbits in each group and allocated to five dietary treatments individually. Thus, each treatment had four replicates in a complete randomized design. The five test diets were formulated to contain approximately $18 \%$ crude protein and 3,000 kcal/kg metabolizable energy (ME) in which Tridax procumbens was included at $0 \%, 5 \%, 10 \%, 15 \%$ and $20 \%$ levels for dietary treatment T1,T2, T3, T4 and T5 respectively. Results obtained indicate increased average daily feed intake, Average Daily Weight gain and improved feed to gain ratio $(P<0.05)$ in rabbits for T3 diet as compared to those on the other diets. Linear regression and co-relation analysis between the levels of Tridax procumbens inclusion indicate a significant negative relationship with average daily feed intake $(r=-0.92)$, the relationship was however negative but not significant when the level of Tridax procumbens was compared to average daily weight gain $(r=-0.33)$ and feed/gain ratio $(r=-0.25)$. It was thus concluded that Tridax procumbent can be added in cassava-based rations for growing rabbits and performance maximized at $10 \%$ inclusion level and this level (10\%) is here recommended for adoption by farmers.
\end{abstract}

Key words: Cassava root meal, Rabbits, Tridax procumbens

\section{Introduction}

The shortage of protein particularly of animal origin in human diets in all parts of Africa and most developing countries of the world has been well documented [1]. The production of non - ruminant species and indeed rabbits represents the fastest means of correcting the shortage of animal protein in tropical Africa [2].

Since the pioneering works [3], [4] in Nigeria, several researchers [5], [6], [7] have confirmed cassava as a primary source of energy and its suitability as a good substitute for maize in the diets of all classes of farm animals. Cassava tuber is however reported to be low in essential minerals [8] protein [6] poor amino acid profile [9]; its high energy content [10], [11] makes cassava a potential cheap source of energy for animals provided the diet is well balanced.

Forages offer a considerable potential as a major source of energy, proteins, minerals, and vitamins for herbivorous animals [12]. Tridax procumbens, a tropical forage of compositae family is reported as having great potential for use as livestock feed ingredient [13] It has crude protein values ranging from $15-22 \%$ depending on time of harvest [14], [15], high in mineral (ash) depending on stage of maturity [16]and high in essential amino acid content [17], [16]. Rabbits in the tropics are said to prefer Tridax procumbens compared to other forage species [18] and because of its nutrient profile, Tridax procumbens can be used to supplement nutrient deficiencies found in cassava tubers.

The objective of this study is to determine the performance of growing rabbits fed different inclusion levels of Tridax procumbens in cassava based ration with the view of determining a level that supports optimum performance with respect to feed intake, weight gain, feed to gain ratio and economics of feeding as well as a most economical level of inclusion. 


\section{Materials and methods}

Twenty, 6 weeks old cross - bred weaner rabbits of mixed sexes with average initial weight of $645 \pm$ $49.37 \mathrm{~g}$ were randomly allocated to five dietary treatments on the basis of sex and weight. The rabbits were individually housed in cages which allowed for ad libitum access to feed and water throughout the twelve weeks trial. Data on feed consumption, and weight gain were collected weekly and feed to gain ratio, feed cost and cost of feeding computed.

\subsection{Preparation of dietary components}

Cassava root meal (CRM): Composite cassava roots were purchased from the open market within the study area. The roots were cleaned of sand and other foreign materials and then, sliced into chips measuring about $0.50-1.00 \mathrm{~cm}$ in diameter. The chips were then sundried on concrete floor for $5-6$ days, after which, they were milled to give cassava root meal.

Roasted full - fat soyabean: Raw full - fat soyabeans was also purchased from the open market and heat treated by roasting as described [19]. After roasting, the soyabean was spread on concrete floor, allowed to cool, milled and packed into bags.

Tridax procumbens: Fresh Tridax procumbens was harvested within the study area. It was obtained by harvesting whole plant (stem and leaves) above a $3 \mathrm{~cm}$ stubble height within the mid vegetative to early flowering stage of development as described [13].

The harvested forage were then sundried on concrete floor for $5-6$ days in not too harsh sun to prevent bleaching and out of the rain to prevent leaching until completely dry in such a manner that the dried forage still maintained its green colouration. The dried Tridax procumbens was then pounded and milled using a burr mill. The milled material was then stored in air tight plastic container until incorporated in the test diets.

"Burukuru" spent grain: Burukutu spent grain (by-product of locally brewed alcoholic beverage using red sorghum grains) was obtained from local brewers and sundried for $4-5$ days, milled for later use in test diets.

\subsection{Chemical Analysis}

Proximate Analysis : Proximate chemical analysis of dietary ingredients Cassava Root Meal (CRM), Full - Fat Roasted Soyabeans (FFSB), Tridax procumbens, Rice Husk (RH) and Dried Burukutu Spent Grain (DBSG) ( Table 1) and the test diets (Table 3) was carried out in accordance with standard procedure [20].

Mineral Analysis: Samples of Tridax procumbens were analysed for phosphorus (P) using the method of Kitson and Mellon as described [21], calcium (Ca), magnesium (Mg) and manganese (Mn) were determined using the atomic absorption spectrophotometer as outlined [21]. Potassium (K) and sodium (Na) were determined using flame photometry as outlined [21] and shown in Table 2.

Amino Acid Analysis: A sample of the processed Tridax procumbens was defatted and hydrolysed for the determination of amino acid profile of the forage (Table 2) as described [22].

\subsection{Experimental diets}

Five dietary treatments T1, T2, T3, T4 and T5 corresponding to $0 \%, 5 \%, 10 \%, 15 \%$ and $20 \%$ levels of added Tridax procumbens respectively were formulated to contain approximately $18 \% \mathrm{CP}$ and $3000 \mathrm{kcal} / \mathrm{kg}$ metabolizable energy.

The composition of the 5 trial diets is summarized in Table 3 . The proximate chemical composition of the test diets is shown in Table 4

\begin{tabular}{llllll} 
Table 1: & $\begin{array}{l}\text { Proximate } \\
\text { matter). }\end{array}$ & Chemical & \multicolumn{6}{l}{ composition of major dietary } & ingredients & (\% Dry \\
\hline Ingred ient & $\begin{array}{l}\text { Ether } \\
\text { extract }\end{array}$ & $\begin{array}{l}\text { Crude } \\
\text { protein }\end{array}$ & $\begin{array}{l}\text { Crude } \\
\text { fibre }\end{array}$ & Ash & NFE \\
& 0.31 & 2.29 & 7.10 & 3.21 & 87.09 \\
& 18.85 & 38.12 & 5.65 & 4.38 & 33.00 \\
Cassava Root Meal & 6.85 & 25.64 & 14.76 & 4.25 & 48.52 \\
Roasted Full-Fat Soyabeans & 9.52 & 6.21 & 34.37 & 18.72 & 31.13 \\
Dried Burukutu Spent Grains. & & & & & \\
Rice husk & & &
\end{tabular}

\subsection{Experimental Design}

The Completely Randomized Design was used. The rabbits were divided into 5 groups with 4 rabbits ( 2 bucks and 2 does) in each group and allocated individually into 5 dietary treatments. Thus, there were 4 replicates in each treatment with each rabbit serving as an experimental unit. 


\subsection{Statistical Analysis}

All data obtained were subjected to Analysis of Variance (ANOVA) for Complete Randomized Design (CRD) significant differences $(\mathrm{P}<0.05)$ between treatment mean separated using the Duncans Multiple Range Test (DMRT). ANOVA and DMRT were carried out in accordance with the procedure [23]. Linear regression was carried out to determine the relationship between levels of Tridax procumbens inclusion and performance traits.

\section{Results and Discussion}

Proximate analysis (Table 1) revealed that Tridax procumbens is relatively high in protein $(22.16 \%)$ and fibre $(30.21 \%)$ content and may be thus classified as a high protein forage material. It is probable that with these attributes, a mixture of CRM and Tridax procumbens will provide a diet that would easily be balanced in formulation for rabbits. The forage is high in minerals especially $\mathrm{K}, \mathrm{P}, \mathrm{Ca}$ and $\mathrm{Fe}$, but lower in $\mathrm{Na}, \mathrm{Zn}$ and $\mathrm{Cu}$ compared to alfalfa. Compared to published values of maize, sorghum and full - fat soyabeans as reported [24], Tridax procumbens has higher content of $\mathrm{Na}, \mathrm{K}, \mathrm{Mg}, \mathrm{Cu}, \mathrm{Fe}, \mathrm{Zn}$ and $\mathrm{Mn}$. It is therefore feasible that the high mineral content of Tridax procumbens can compensate for the low mineral content in cassava. The amino acid profile will also help improve feed intake and utilization of cassava based diets.

\begin{tabular}{|c|c|c|c|c|c|}
\hline $\begin{array}{l}\text { Proximate } \\
\text { Composition (\%) }\end{array}$ & Content & Minerals & Content & Amino acids $(\mathrm{g} / 16 \mathrm{gN})$ & Content \\
\hline Crude protein & 22.16 & $\mathrm{~K}(\%)$ & 4.60 & Lysine & 7.11 \\
\hline Crude fibre & 30.21 & $\mathrm{Na}(\%)$ & 0.02 & Histidine & 1.67 \\
\hline Ether ex tract & 3.86 & $\mathrm{P}(\%)$ & 0.60 & Arginine & 4.03 \\
\hline Ash & 15.36 & $\mathrm{Ca}(\%)$ & 2.42 & Aspartic acid & 9.52 \\
\hline NFE & 28.41 & $\mathrm{Mg}(\%)$ & 0.31 & Threonine & 4.57 \\
\hline - & - & $\mathrm{Fe}(\mathrm{ppm})$ & 238.95 & Serine & 5.90 \\
\hline - & - & $\mathrm{Mn}(\mathrm{ppm})$ & 46.15 & Glutam ic acid & 8.49 \\
\hline - & - & $\mathrm{Cu}(\mathrm{ppm})$ & 1.00 & Proline & 1.79 \\
\hline - & - & $\mathrm{Zn}(\mathrm{ppm})$ & 104.98 & Glycine & 5.75 \\
\hline - & - & - & - & Alanine & 6.16 \\
\hline - & - & - & - & Cystine & 1.20 \\
\hline - & - & - & - & Valine & 4.19 \\
\hline - & - & - & - & Methionine & 0.54 \\
\hline - & - & - & - & Isoleucine & 3.68 \\
\hline - & - & - & - & Leucine & 7.84 \\
\hline - & - & - & - & Tyrosine & 2.62 \\
\hline - & - & - & - & Pherylalam ine & 3.88 \\
\hline
\end{tabular}

Table 3:Percent composition of experimental diets

\begin{tabular}{|c|c|c|c|c|c|}
\hline \multirow{2}{*}{ Ingredients } & \multicolumn{5}{|c|}{ Dietary Treatment } \\
\hline & $\mathrm{T}_{1}$ & $\mathrm{~T}_{2}$ & $\mathrm{~T}_{3}$ & $\mathrm{~T}_{4}$ & $\mathrm{~T}_{5}$ \\
\hline Cassava root meal & 40.00 & 40.00 & 40.00 & 40.00 & 40.00 \\
\hline Roasted full fat soyabean & 35.00 & 34.00 & 33.00 & 32.00 & 30.00 \\
\hline Tridax procum bens & 0.00 & 5.00 & 10.00 & 15.00 & 20.00 \\
\hline Burukutu spent grain & 10.50 & 8.00 & 5.50 & 3.00 & 2.50 \\
\hline Rice hus: & 10.00 & 8.50 & 7.00 & 5.50 & 3.00 \\
\hline Bone meal & 2.50 & 2.50 & 2.50 & 2.50 & 2.50 \\
\hline Palm oil & 1.00 & 1.00 & 1.00 & 1.00 & 1.00 \\
\hline Salt & 0.50 & 0.50 & 0.50 & 0.50 & 0.50 \\
\hline Sugar & 0.50 & 0.50 & 0.50 & 0.50 & 0.50 \\
\hline Premix ${ }^{2}$ & + & + & + & + & + \\
\hline Coccidiostat $^{b}$ & + & + & + & + & + \\
\hline \multicolumn{6}{|c|}{ Proximate Composition of Experimental Diets } \\
\hline Ether ex tract & 8.16 & 8.14 & 7.52 & 7.39 & 6.78 \\
\hline Crude protein & 18.20 & 18.22 & 18.18 & 18.20 & 18.36 \\
\hline Crude fiber & 9.69 & 10.22 & 10.67 & 11.46 & 11.88 \\
\hline Ash & 5.12 & 5.17 & 5.23 & 5.28 & 5.18 \\
\hline $\mathrm{NFE}^{\mathrm{a}}$ & 58.83 & 58.25 & 58.40 & 57.67 & 57.18 \\
\hline $\mathrm{ME}(\mathrm{Kcal} / \mathrm{kg} \operatorname{diet})^{\mathrm{b}}$ & 3066.40 & 3012.00 & 2871.40 & 2931.20 & 2868.80 \\
\hline
\end{tabular}

The performance data on live weight gain, feed intake feed/grain ratio are as summarized in Table 5.The average daily feed intake decreased as the level of Tridax procumbens increased in the diets, indicating a significant negative $(r-0.92)$ relationship between level Tridax inclusion and average daily feed intake. Average daily feed intake in the $T_{1}$ diet was signicantly higher $(P<0.05)$ than the values obtained for $T_{4}$ and $T_{5}$ feed rabbits but not $(\mathrm{P}>0.05)$ for the $\mathrm{T}_{2}$ and $\mathrm{T}_{3}$ fed rabbits. The results obtained in this study are higher than that reported [25], [26], [27] and [28] when they feed various levels of cassava to rabbits. The finding in this study also disagree with the report [28] that cassava should not be used beyond $30 \%$ level of inclusion for rabbits. The observed higher performance of rabbits in this study even at $40 \%$ level of inclusion is probably due to better nutrient balance in the diets due to Tridax procumpens inclusion. The observed generally lower average daily feed intake values with increasing levels of Tridax procumbens may be attributed to increase bulk and fluffy 
nature of diets resulting from the inclusion of Tridax procumpens. It is expected that feed intake of the diets $\left(\mathrm{T}_{2}\right.$ $-\mathrm{T}_{5}$ ) should increase due to decreasing ME energy levels of the diets. This was not however the case due to increase bulk of the feed.

The results obtained are similar to the range reported [30] when they fed brewer's yeast slurred cassava root meal in the diets of rabbits. These researchers obtained daily feed intake range of $50.09-56.78 \mathrm{~g} / \mathrm{rabbit} /$ day compared to the $52.96-59.87 \mathrm{~g} / \mathrm{rabbit} /$ day obtained in this study.

The average daily gain was highest with rabbits fed the $T_{3}$ diet and lowest in the $T_{5}$ fed rabbits fed rabbits. Rabbits on the $\mathrm{T}_{3}$ diet showed significantly higher $(\mathrm{P}<0.05)$ average daily weight gain companied to those fed the $T_{2}, T_{4}$ and $T_{5}$ but not $(P<0.05)$ to those fed the $T_{1}$ diet. The relationship between Tridax procumpens inclusion and average daily gain was negative $(\mathrm{r}=-0.33)$ but not significant. The average daily gain (ADG) range obtained in this study is slightly higher than the 16.72-18.53g/ rabbit/day reported [31] when he fed $0-45 \%$ level of cassava root meal diet to fryer rabbits. It is also higher than the $12.9614 .18 \mathrm{~g} / \mathrm{rabbit} / \mathrm{day}$ reported [25] as well as the 13.04-15.72g /rabbit/ day reported [30] when they fed different forms of cassava diet to growing rabbits. The higher gain of rabbits in this study (18.82-19.63g /rabbit/ day is in agreement with [9] who reported an improved performance of rabbit on cassava root meal diet when $2 \%$. Palm oil and $20 \mathrm{~g}$ of green herbage (Aspila africana) was added to their diet, thus agreeing that protein digestion and utilization thus general performance of rabbits can be improved with the addition of forage in rabbit diet as reported [33]. It can be thus deduced that the improved weight gain for the rabbits in this study is as a result of Tridax Procubens inclusion in the diets and not energy since it is not possible to increase growth rate of rabbits by modifying the energy content of the diets of rabbits as reported [34].

The rabbits on the $\mathrm{T}_{3}$ diet needed $2.84 \mathrm{~g}$ of feed for each gram of weight gained. Feed/gain ratio was negatively correlate to dietary level of Tridax procumbens inclusion however, this relation $(r-0.25)$ was not significant. Rabbits in this study converted feed to body tissue better than in most reported works within the study area. The lower feed/gain ratio range $2.62-4.78$ obtained in this study may be due to better utilization of the diet resulting from the inclusion of Tridax procumbens as it is nutrient base richly compensated for most deficiencies found in the nutrient composition of cassava.

\section{Conclusion}

The performance of rabbis fed cassava based diets with Tridax procumbens inclusion promoted better feed utilization than rabbits reared within the same study area. Rabbits can tolerate cassava based diets with more than $30 \%$ cassava inclusion without adverse effect on performance provided Tridax procumbens is included in the diets.

Table 4: Utilization of Trickax procumbers in cassava based rations on performance and economy of
feeding growing rabbits.

\section{References}

[1]. Bawa, G.S. Ogundipe, S.O, Tsegbe, T.S.B. and Dagwang, I.I. (2009). Effect of cooking time on the nutritive value of lablab seed in diets of young pigs. Nig. J. Anim. Prod. Vol 26: (i) 74-84.

[2]. Apata, D.F. and Ojo, V. (2000). Efficacy of Trichoderma viride enzyme complex in broiler starter fed cowpea testa based diets. In Animal Production in the New Millennium, Changes Options. Nigerian Society for Animal Production (S.N. Uwachukwu et al. eds) 25th Annual Conf. Michael Okpara University of Agriculture, Umudike, Abia State 19 - 23 March, 2000, pp 23 - 133

[3]. Oyenuga,V.A. and Opeke,L.K. (1957). The value of cereal and cassava diet for growing fattening pigs in Nigeria. Brit. J. Nutr. 15: 327 - 333. Modebe,A.M.A. (1963).Preliminary trial on the value of dried cassava for pig feeding. J.West Afri. Sci. Asso. 7:127133.

[4]. Modebe,A.M.A. (1963).Preliminary trial on the value of dried cassava for pig feeding. J.West Afri. Sci. Asso. 7:127-133. 
[5]. Adegbola, A.A. Methionine as additive to cassava as livestock feed. An Invited Paper on Workshop on Utilization of Cassava as Livestock Feed. University of Guelph, 13 - 20 April, 1977 Ontario, Canada, pp 612 - 614.

[6]. Hahn,S.K.(1988).Cassava as livestock feed in Africa. In. Proceeding of the IITA/ILCA/University of Ibadan Workshop on Potential Utilization of Cassava in Africa.,University of Ibadan 24th - 28th March 1988. Pp 3 - 4.

[7]. Nghi, N. (1984). Determination of chemical composition of sweet potatoes and cassava cultivated in Vietnam and the utilization of cassava meal as pig feed. Report No. 22. In Proc. Workshop on Swine and Poultry Husbandry $11-15$ August, 1986 Bali, Indonesia. IFS (International Foundation of Science), pp $89-91$.

[8]. Onwueme,I.C. (1978), Tropical tuber crops (Yam, Cassava sweet potatoes and cocoyam) John Wiley Publ. Pp. 17-24.

[9]. Omole, T.A. (1977). Effect of graded levels of copper in the diets of growing rabbits on their performance, carcass andorgan measurements. Nig. J. Anim. Prod. 3: $11-95$.

[10]. Oke,O.L. (1978). Problems in the use of cassava as animal feed. J. Anim. Sci. 3: $343-380$.

[11]. Fisinin,V. Geev,A. and Ezerskaya, C. (1980). Tapioca in diets for broilers. Ptitge Vodsto 11: 12 - 14

[12]. Crowder, R. and Chadha, M. (1982). Effect of type of fibre on the rate of passage and on the contribution of soft faeces in nutrients of finishing rabbits. J. Appl. Rabbit Res. 15: 1008 - 1016.

[13]. Kalu,B.A., Njike, M.C. and Ikurior, S. A. (1986a). evaluating the potential of Tridax procumbens for livestock feed. I.Morphological stages of development and chemical composition. Nig. J. Anim. Prod. 13: $11-12$.

[14]. Kalu,B.A., Njike, M.C. and Ikurior, S. A. (1986b). evaluating the potential of Tridax procumbens for livestock feed. II.

[15]. Seasonal changes in chemical composition. Nig. J. Anim. Prod. 13: $23-28$.

[16]. Aduku,A.O.(1993). Tropical Feedstuff Nutrient Analysis Table. Ahmadu Bello University, Zaria, Nigeria.

[17]. Anthony, T. I., Onuh, S.O. and Ortserga, D. D. (2007). Proximate composition, nutritional content and amino acid profile of Tridax procumbens from Yandev, Benue State. Nigerian Journal of Sustainable Tropical Agricultural Research 24: 38 - 41.

[18]. Ojobe, T.L (1998) Amino acid composition of plant materials feed to fish. Ph. D. Thesis Department of Zoology, University of Jos, Nigeria.

[19]. Aduku,A.O.,Dim,N.I.and Aganga,A.A. (1988). Evaluation of palm kernel meal, peanut and sunflower meal in diets for weaning rabbits. J. Appl. Rabbit Res. 11: 264 - 265.

[20]. Ikurior, S.A, Torhee, S.A, and Anthony, T.I. (1992) Effect of full-fat cooked or roasted soyabeans and soyabeans meal on performance and carcass characteristics of growing-finishing pigs. J. Sci. Food and Agric. 649-658.A.O.A.C. (2000). Association of Official Analytical Chemists. Official methods of analysis. 16th Ed. Washington D.C.,U.S.A.

[21]. Church, D.C., Pond, W.G. and Pond, D.C. (1995). Basic Animal Nutrition and Feeding, 4th Edition. Publ. John Wiley and Don New York, pp $17-25$.

[22]. Spackman, D.H.,Stem,W.H. and More,S. (1958). Automatic Recording Apparatus for Use in the Chromatography Amino Acid Chemistry. Academy Press London, pp 90 - 97.

[23]. Steel, R.G.D. and Torrie (1984). Principles and Procedures of Statistics. A Biometric Approach. McGraw Hill Inc. New York, U.S.A.

[24]. Larbier, M. and Leclereq,B. (1994). Nutrition and Feeding of Poultry. Nottingham University Press, pp $62-69$

[25]. Onifade, A.A. and Tewe, O.O. (1998). Alternative tropical energy feed resources in rabbit diet. Growth performance, diet digestibility and blood composition World Rabbit Science 3 (i): 17-24.

[26]. Anugwa, F.O.I, Adesua, M. and Ikurior .S.A. (1998). Effects of dietary crude fibre levels on performance, nutrients digestibility and carcass characteristics of weanling-growing rabbits. In: proc. Silver Anniversary conf. of NASA/WSAP inaugural Conf. Abeokuta march 2126, 327-328.pp.

[27]. Biobaku, W.O, Aiyegbo A. and Arewa O, B. (2002). The effects of feeding raw and cooked luencaena leucocephela seedbean on the performance of rabbits in proceeding of 27th Ann. Conf. Nig. Soc. for Anim. Prod. (NSAP) march 17-21-2002 feed. Univ of Tech Akure Nigeria. 125-127 PP.

[28]. Oluponna, J.A, Aboduawa, J.A, Adejinmi, O.O Ogunleke, F.O, Fapalunda, J.B. and Olubadin o.o. (2002) performance of rabbits fed b rewers' dried grins from different sources. In: proc. 27th Ann, Conf. Nig. Soc. for Anim. Rpod, (NSAP) march 17-21-2002 fed. Univ of Tech. Akure Nigeria pp 239-241.Eshiet N.O (1977).The effect of feeding cassava root meal on the reproductive performance of rabbits.J.Nut 110(4):697-702.

[29]. Eshiet N.O (1977).The effect of feeding cassava root meal on the reproductive performance of rabbits.J.Nut 110(4):697-702.

[30]. Ikurior, S.A and Akem, J.D. (1998). Replacing maize with cassavas root meal or its mixture with brewer's yeast slurry in rabbits diet. Nig J. Anim. Pro. 25 (i): 31-35.

[31]. Omole, T.A. (1988). Use o0f cassava for feeding rabbits. In proc. Of IITA/ILCA/University of Ibadan workshop ofcassava as livestock feed in Africa. 14-18 November 1988 Ibadan Nigeria pp 58-71.

[32]. Onifade, A.A. and Tewe, O.O. (1993). Alternative tropical energy feed resources in rabbit diet. Growth performance, diet digestibility and blood composition World Rabbit Science 3 (i): 17-24.

[33]. Aquilera, J. (1973). Influence of protein levels of the diet on digestibility nutritive value and nitrogen balance in growing rabbits. Proc. Of int. conv. On rabbits pro. Italy 188-193.

[34]. Lebas, F. Laplaces, J.P and Dromeng, P. (1982). Effect of dietary energy content in rabbits feed. Variations according to age of animal and feeding sequence Ann. Zootech. 31:233-256. 